\title{
Fulminant Hepatitis Following Ritonavir-Nevirapine-Efavirenz Regimen in a Female HIV Patient in Pointe-Noire in 2016
}

\author{
Firmin Bossali ${ }^{*}$, G. Ndziessi², G. Deby ${ }^{3}$, C. R. Ahoui Apendi³, J. F. Mimiesse³, B. I. Atipo-Ibara ${ }^{3}$, \\ J. R. Ibara ${ }^{3}$ \\ ${ }^{1}$ Gastroenterology Department, General Hospital of Loandjili, Pointe-Noire, Congo \\ ${ }^{2}$ Faculty of Health Sciences, Brazzaville, Congo \\ ${ }^{3}$ Gastroenterology Department-CHU, Brazzaville, Congo \\ Email: *firminbossali@yahoo.fr
}

How to cite this paper: Bossali, F., Ndziessi, G., Deby, G., Ahoui Apendi, C.R., Mimiesse, J.F., Atipo-Ibara, B.I. and Ibara, J.R. (2018) Fulminant Hepatitis Following RitonavirNevirapine-Efavirenz Regimen in a Female HIV Patient in Pointe-Noire in 2016. Open Journal of Gastroenterology, 8, 167-171. https://doi.org/10.4236/ojgas.2018.85019

Received: April 16, 2018

Accepted: May 13, 2018

Published: May 16, 2018

Copyright $\odot 2018$ by authors and Scientific Research Publishing Inc. This work is licensed under the Creative Commons Attribution International License (CC BY 4.0).

http://creativecommons.org/licenses/by/4.0/

\begin{abstract}
Current antiretroviral therapy has reduced morbidity and mortality of HIV patients. However, their induced hepatotoxicity constitutes a risk. In this issue, we report a clinical case of fulminant hepatitis, observed in the HIV unit of the hepatogastroenterology department of the General hospital of Loandjili in Pointe-Noire. The patient is a 36-year-old female HIV treated with triple-dug combination antiretroviral therapies (ART) including one antiprotease (ritonavir) and two non-nucleoside reverse transcriptase inhibitors (nevirapine and efavirenz). He developed fulminant hepatitis five years after treatment initiation. He succumbed to the side effects. Although antiretroviral combination therapies are the standard of care for HIV infection, increased vigilance is warranted to early identify this side effect and adjust treatment in order to prevent fatal consequences.
\end{abstract}

\section{Keywords}

Fulminant Hepatitis, Hepatotoxicity, Antiretroviral Therapy, Pointe-Noire

\section{Introduction}

Combination of antiretroviral therapies (ART) has transformed the natural history of human immunodeficiency virus (HIV) infection with a significant reduction in morbidity and mortality from opportunistic infections. However, some of the ARTs are labelled as hepatotoxic, thus constituting a potential risk for morbidity and mortality, especially in patients co-infected with the hepatitis B or hepatitis $\mathrm{C}$ viruses, and in alcoholic patients. Hepatotoxic ARTs belong to the 
following therapeutic classes: nucleoside reverse transcriptase inhibitors (NRTIs); non-nucleoside reverse transcriptase inhibitors (NNTRIs) and protease inhibitors (PIs) [1] [2] [3]. We report in this article a clinical case of drug-induced hepatitis with fatal outcome due to ART, observed in one patient in the HIV unit of the hepatogastroenterology department of the General Hospital of Loandjili in Pointe-Noire.

\section{Case Report}

Mrs. BA. M., 36, was admitted to the ward on $04 / 08 / 2016$ for jaundice, asthenia and lower-extremity edema. She had type $1 \mathrm{HIV}$ infection discovered during prolonged diarrhoea. After an enlightened counseling and her adherence to treatment, she was admitted to our active line of patients followed for HIV +. When included for treatment, T4 (CD4) cells were at 123 cells $/ \mathrm{mm}^{3}$. Transaminases were $35 \mathrm{IU}$ for AST and $28 \mathrm{IU}$ for ALT. She was administered highly active antiretroviral therapy (HAART) including one protease inhibitor, ritonavir 100 mgx2/ day and two non-nucleoside reverse transcriptase inhibitors: nevirapine $400 \mathrm{mg} /$ day and efavirenz $600 \mathrm{mg} /$ day. The patient regularly followed this treatment until the onset of asthenia, jaundice and lower-extremity edema which prompted hospitalization on April 8, 2016, 5 years after the treatment initiation. Mother of 02 children, she was married to a 53-year-old man infected with type-1 HIV under ART and not followed in our hospital.

\subsection{Physical Examination}

The general state was preserved on admission, the temperature was $37^{\circ} \mathrm{C}$, weight $85 \mathrm{~kg}$, height $1.68 \mathrm{~m}$ and body mass index (BMI) of $30 \mathrm{Kg} / \mathrm{m}^{2}$. Performance Status of the WHO was 2 and KARNOWSKY index was $60 \%$. The neurological examination noted slight apathy. The blood pressure was $136 \mathrm{mmg} / 80 \mathrm{mmg}$ with a pulse rate at 78/minute. There was jaundice and cold, painless and pitting lower extremity edema. On abdominal examination there was painful hepatomegaly, with sharp liver edge and no hepatojugular reflux; the liver span was at $16 \mathrm{~cm}$ on the midoclavicular line. The chest X-ray showed an elevation of the right diaphragmatic cupola, suggestive of hepatomegaly (Figure 1), confirmed by abdominal ultrasound showing a homogeneous, hyperechoic liver with a hepatic arrow measured at $170 \mathrm{~mm}$ (Figure 2(a) and Figure 2(b)). Upper digestve fibroscopy was normal. Erythrocyte sedimentation rate was $37 \mathrm{~mm}$; there was leukocytosis at 13,800 cells $/ \mathrm{mm}^{3}$, the lymphocytes at $4470 \mathrm{cells} / \mathrm{mm}^{3}$; the CD4 cell count was 137 cells $/ \mathrm{mm}^{3}$. Glucosemia was $1.13 \mathrm{~g} / \mathrm{L} \mathrm{g} / \mathrm{l}$; serum creatinemia was $5.7 \mathrm{mg} / \mathrm{L}$; cholesterol was $0.68 \mathrm{~g} / \mathrm{L}$; total bilirubinemia was $254 \mathrm{mg} / \mathrm{L}$ with $182 \mathrm{mg} / \mathrm{L}$ being the conjugated fraction; Alkaline phosphatases were at 130UI; gammaglutamyl transpeptidase (GGT) was 28UI; ASTs were at 652UI; ALT was 382UI. The prothrombin and factor $\mathrm{V}$ levels were incalculable due to the total incoagulability of the blood; the Kaolin partial thromboplastin time was 83.5 seconds for the patient compared to 28.7 seconds for the control. Viral markers 


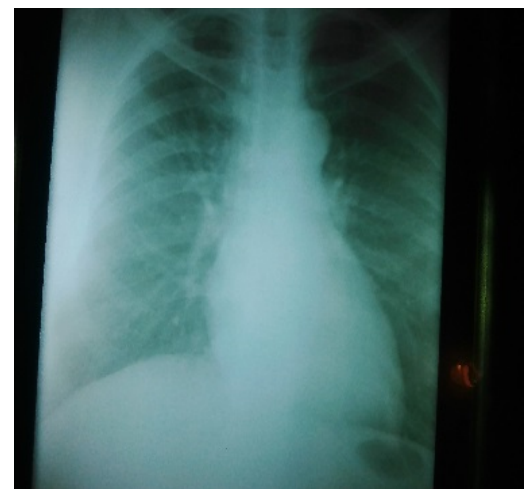

Figure 1. Chest X-ray.

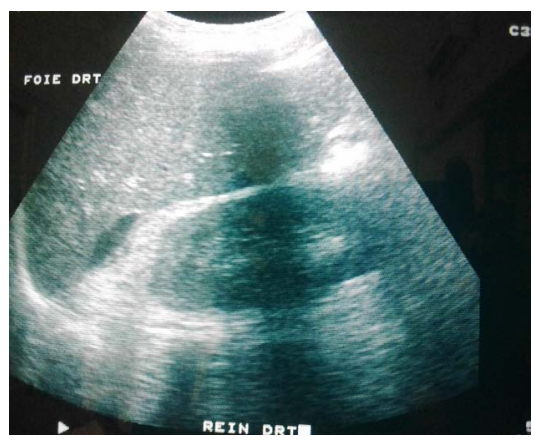

(a)

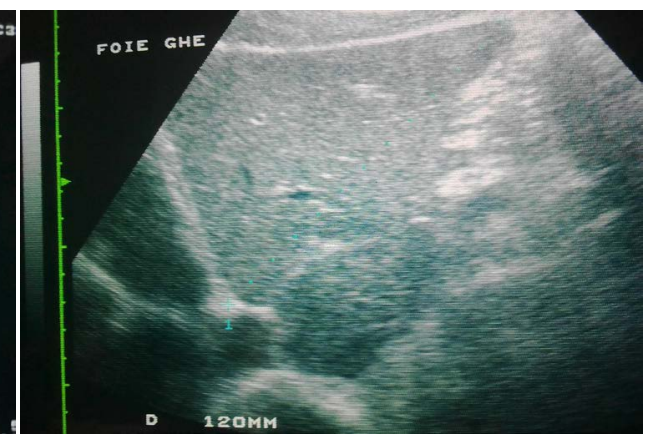

(b)

Figure 2. Hepatomegaly.

for hepatitis A, B and C were negative and the viral load of HIV was not measured; the alphafoetoprotein level was $2073 \mathrm{IU} / \mathrm{ml}$. The electrophoresis of proteins showed polyclonal hypergammaglobulinemia at $34.5 \mathrm{~g} / \mathrm{L}$; the total protein concentration was $75 \mathrm{~g} / \mathrm{L}$ with an albumin level of $33.7 \mathrm{~g} / \mathrm{L}$. The serum natremia was $135 \mathrm{Meq} / \mathrm{L}$; serum kalemia at $2.8 \mathrm{Meq} / \mathrm{L}$ and chloremia at $99 \mathrm{Meq} / \mathrm{L}$.

\subsection{Summary}

Mrs BA. M. 36 years old, HIV AIDS patient with a very low CD4 level treated with combination of two reverse transcriptase inhibitors (nevirapine and efavirenz) and one protease inhibitor (ritonavir) presented a stage 4 drug-induced cytolitic hepatitis according to the AIDS clinical trial group scale of liver toxicity. Following that, we hospitalized him and put him on parenteral treatment, including methylprednisolone $1 \mathrm{mg} / \mathrm{kg} /$ day, vitamin $\mathrm{K} 1150 \mathrm{mg} / \mathrm{day}$, furosemide 20 $\mathrm{mg} /$ day. The evolution was rapidly worsening with onset of a hepatorenal syndrome with creatinemia at $120 \mathrm{mg} / \mathrm{L}$, uremia at $3 \mathrm{~g} / \mathrm{L}$ followed by acute pulmonary edema, cardiac arrest and death the 8th day of hospitalization on $15 / 04 / 2016$

\section{Discussion}

The antiviral hepatotoxicity factors described in previous studies are: viral 
co-infection B and C, herpes or cytomegalovirus; lymphoma, KAPOSI sarcoma; alcoholism; bacterial or fungal infection; consumption of HAART recognized as hepatotoxic; other hepatotoxic drugs including nonsteroidal anti-inflammatory drugs, corticosteroids, cotrimoxazole, quinolones, anti-tuberculosis drugs, $\beta$-lactams and psychotropic drugs [1] [2]. In our patient, the diagnosis of drug-induced hepatitis with ARTs was made according to the following criteria: the elevation of ASTs more than ALTs which is an indication of toxic cytolysis and the survey conducted with the patient and her entourage did not find the notion of taking other drugs or substances recognized as hepatotoxic. The mechanisms of hepatotoxicity of ARTs are: direct toxicity, idiosyncrasy, hypersensitivity, mitochondrial, metabolic steatosis, immune restoration, and viral co-infection B or C [3]. We support the hypothesis of hepatotoxicity by metabolic and/or mitochondrial steatosis on the basis of overweight and liver function disturbances. The incidence of hepatotoxicity due to ARTs varies from $2 \%$ to $18 \%$ according to some studies [4]. These differences are related to the absence of standards in the definition of ART-induced hepatotoxicity, justifying the adoption of AIDS clinical trial group scale of liver toxicity (Table 1). In the therapeutic class of non-nucleoside reverse transcriptase inhibitors, nevirapine and efavirenz are the most incriminated molecules whereas in the class of protease inhibitors, atazanavir, tipranavir, ritonavir and indinavir are the most incriminated molecules [4]. Thus, consumption of these drugs is a risk factor for hepatotoxicity the same way as low level of CD4 count, male sex, advanced age, alcoholism, obesity and metabolic steatosis, co-infection with virus $\mathrm{B}$ or $\mathrm{C}$, advanced fibrosis F3-F4, cirrhosis and previous cytolytic liver disease. Thus, it is strongly recommended that all these comorbidities be screened before HAART is initiated and regular monitoring of liver function be scheduled for patients treated every three months [1] [3] [4]. ART-induced hepatotoxicity is defined as high in transaminases and/or bilirubin after initiation of HAART in a treated patient. Indeed, transaminases and bilirubin are two independent or associated biochemical markers of hepatotoxicity. And these two markers are used as part of the evaluation of the severity of ART-induced hepatitis as shown in Table 1 . According to this classification, severe hepatotoxicity is defined by grade 3 and 4 [3] [4]. Our patient had three risk factors: low CD4 count, overweight, metabolic

Table 1. AIDS clinical trial group scale of liver toxicity.

\begin{tabular}{ccc}
\hline Stages & Aspartate aminotransferase (AST) in UI & Bilirubinemia in mg/l \\
\hline 0 & $<1.25 \mathrm{xN}$ & $<1.1 \mathrm{xN}$ \\
1 & $1.25-2.5 \mathrm{xN}$ & $1.1-1.5 \mathrm{xN}$ \\
2 & $2.6-5 \mathrm{xN}$ & $1.6-2.9 \mathrm{xN}$ \\
3 & $5.1-10 \mathrm{xN}$ & $3.5 \mathrm{xN}$ \\
4 & $>10 \mathrm{xN}$ & $>5 \mathrm{xN}$
\end{tabular}

Legendary: $\mathrm{x}$ = times; N = reference value; Sources: Kontorinis N, Dieterich D. (2003) hepatotoxicity of antiretroviral therapy. AIDS Rev 5:36-43. 
steatosis associated with intakes of nevirapine, efavirenz, and ritonavir. The reason for this non-standard combination has been the lack of other antiretroviral therapeutic lines in our context [5].

\section{Conclusion}

This clinical case was about fulminant hepatitis due to combination of antiretroviral therapy including two non-nucleoside reverse transcriptase inhibitors and one protease inhibitor. Although HAART is currently the standard of care for HIV infection, hepatotoxicity of some molecules prompts increased vigilance to identify early side effects and adjust treatments.

\section{References}

[1] Gervais, A. (2009) Hépatotoxicité des antirétroviraux. Hépato-Gastro, 16, 93-99.

[2] Wambani, J.R., Olga, P.E., Arika, W.M., et al. (2015) Antiretroviral Drug Hepatotoxicity and Risk Factors in HIV Patients with or without Hepatitis B and C: A Review. Journal of Infectious Diseases and Therapy, 3, 258.

[3] Labarga, P., Soriano, V., Vispo, M.E., et al. (2007) Hepatotoxicity of Antiretroviral Drugs Is Reduced after Successful Treatment of Chronic Hepatitis C in HIV-Infected Patients. The Journal of Infectious Diseases, 196, 670-676. https://doi.org/10.1086/520092

[4] Brunon, R., Sacchi, P., Maiocchi, L., et al. (2006) Hepatotoxicity and Antiretroviral Therapy with Protease Inhibitors. A Review. Digestive and Liver Disease, 38, 363-373. https://doi.org/10.1016/j.dld.2006.01.020

[5] Bossali, F., Gassaye, D., Atipo-Ibara, B.I., Ndziessi, G. and Ibara, J.R. (2015) Evaluation de la performance des services d'hépatogastroentérologie pour la prise en charge des cirrhotiques au Congo-Brazzaville en 2014. Journal Africain d'Hépato-Gastroentérologie, 9, 58-59. https://doi.org/10.1007/s12157-015-0593-9 